\title{
Hearing Rehabilitation of Single-Sided Deafness: Benefit and Selection Criteria of Bone Anchored Hearing Aid and Contralateral Routing of Signal Hearing Aid
}

\author{
Mi Na Park ${ }^{1,2}$, Shin Young Yoo ${ }^{2}$, Young-Myung Chun ${ }^{2}$, In Seok Moon ${ }^{1}$ and Sung Huhn Kim ${ }^{1}$ \\ ${ }^{1}$ Department of Otorhinolaryngology, Yonsei University College of Medicine, Seoul; and ${ }^{2}$ Soree Ear Clinic, Seoul, Korea
}

일측성 전농 환자에서의 청력 재활: 바하와 크로스 보청기의 이득과 선택 기준

박미나 ${ }^{1,2} \cdot$ 유신영 $^{2} \cdot$ 전영명 $^{2} \cdot$ 문인석 $^{1} \cdot$ 김성헌 $^{1}$

연세대학교 의과대학 이비인후과학교실, ${ }^{1}$ 소리귀클리닉 ${ }^{2}$

Received March 25, 2013

Revised May 16, 2013

Accepted May 20, 2013

Address for correspondence

Sung Huhn Kim, MD, PhD

Department of Otorhinolaryngology,

Yonsei University

College of Medicine,

50 Yonsei-ro, Seodaemun-gu,

Seoul 120-752, Korea

Tel $+82-2-2228-3622$

Fax $+82-2-393-0580$

E-mail FLEDERMAUS@yuhs.ac
Background and Objectives There are two ways to route sound from a deaf hemifield to a functional ear: the bone anchored hearing aid (BAHA) and the contralateral routing of signal hearing aid (CROS HA). BAHA uses transcranial bone conduction; on the other hand, CROS HA uses air conduction. The objectives of this study were to evaluate the benefit of these auditory rehabilitation devices objectively and subjectively, and to analyze factors that affect daily using time.

Subjects and Method We retrospectively reviewed the medical records of 19 patients who selected BAHA and 9 patients who selected CROS HA to undergo rehabilitation of unilateral hearing loss. Preoperative pure tone air and bone conduction thresholds, BAHA-aided thresholds and CROS HA-aided thresholds were measured. Hearing in noise test (HINT) was measured with unaided and aided in signal to noise ratio 10 (signal $75 \mathrm{~dB}$ HL, noise $65 \mathrm{dBA}$ ). Bern Benefit in Single-Sided Deafness Questionnaire (BBSS) was evaluated for all patients to assess subjective satisfaction and also, daily device using time was investigated.

Results The aided pure tone audiometry was $44.58 \mathrm{~dB}$ HL, $42.71 \mathrm{~dB}$ HL for in BAHA and CROS HA, respectively, whereas the unaided PTA was 111.29, 103.28 dB HL for BAHA and CROS HA, respectively. The aided HINT was 63.03 and $64.06 \%$, whereas the unaided HINT was $22.13 \%$ and $37.44 \%$ for BAHA and CROS, respectively. BBSS showed more satisfactory results with BAHA and CROS HA when compared unaided in all items. Daily using time did not correlate with the degree of satisfaction, better ear hearing levels or etiology.

Conclusion It was found that not only the preoperative BAHA rod test and HA trials but also the customized and detail counseling were needed for single sided deaf patients to use auditory rehabilitation devices frequently. Korean J Otorhinolaryngol-Head Neck Surg 2013;56:339-45

Key Words Bone anchored hearing aids · Contralateral routing of signal hearing aid · Hearing rehabilitation $\cdot$ Single sided deafness.

\section{서 론}

일측성 전농 환자들은 한쪽 귀가 정상 청력임에도 의사소 통에 어려움을 겪는다. 이런 환자들은 농 방향에서 들어오는 소리 식별에 어려움을 겪고, 음원의 방향성을 식별하는 능력
이 감소되며, 특히 소음상황에서 청취에 어려움을 겪는다.,2) 이러한 일측성 전농 환자의 불편함을 감소시키기 위한 청력 재활 수단이 개발되었으며, 크게 골도 보청기와 기도 보청기로 나누어 볼 수 있다.

골도 보청기는 처음에 안경이나 헤어 밴드 형태로 개발이 되 
었으며, 근래에는 bone anchored hearing aid(BAHA)가 개 발되어 일측성 전농인 환자에서 유용하게 사용되고 있다. 기도 보청기는 과거 유선 형태로 개발되었으며, 현재는 무선 형태로 발전되었다. 단순 CROS 보청기(contralateral routing of signal hearing aid)는 일측이 정상이고 반대측이 고도난청인 경우 마이크로폰을 나쁜 쪽으로 장착하고 좋은 쪽에 수화기를 위 치시켜 나쁜 귀 쪽에서 들리는 소리를 좋은 귀 쪽에서 듣게 하 는 장치이다. 양측 $\mathrm{CROS}$ 보청기는 양측 난청으로 나쁜 쪽의 귀로는 보청기로도 들을 수 없고 좋은 귀의 청력도 중등도 혹은 고도 난청이 있는 환자에서, 나쁜 쪽에 마이크로폰을 설 치하고 좋은 쪽에서 증폭하여 양쪽에서 들어오는 소리를 들 을 수 있게 하는 장치이다. ${ }^{3)}$

현재 대부분의 병원에서 BAHA와 CROS 보청기에 대한 선 택 기준이 마련되어 있지 않아, 환자의 선호도에 따라 청력 재
활 수단을 선택하고 있다. 따라서 본 연구에서는 첫째, 일측성 전농 환자에서 BAHA와 CROS 보청기의 기능적 이득(functional gain)을 객관적, 주관적 측면에서 평가하였으며, 둘째, $\mathrm{BAHA}$ 와 CROS 보청기의 하루 착용 시간(daily using time)에 영향을 미치는 요소의 분석을 통해 BAHA와 CROS 보청기의 선택기준을 알아보고자 하였다.

\section{대상 및 방법}

\section{대 상}

2009년 1월부터 2012년 12월까지 일측성 전농 환자 중 BAHA 혹은 $\mathrm{CROS}$ 보청기를 청력 재활 수단으로 선택한 28명을 대상 으로 하였다. 성별은 남자 8명, 여자 20명이었고, 연령은 26세 에서 77 세까지 평균 53.67 세였다.

Table 1. Individual patient data

\begin{tabular}{|c|c|c|c|c|c|c|}
\hline Subject & Gender & Etiology & Age $(y r)$ & Deaf duration (yr) & Device using period (mo) & Group* \\
\hline \multicolumn{7}{|c|}{ BAHA } \\
\hline B1 & $\mathrm{F}$ & COM & 57 & 20 & 42 & B \\
\hline B2 & $\mathrm{F}$ & COM & 52 & 20 & 43 & B \\
\hline B3 & $\mathrm{F}$ & COM & 50 & 20 & 29 & B \\
\hline B4 & $\mathrm{F}$ & COM & 49 & 30 & 12 & B \\
\hline B5 & $\mathrm{F}$ & Congenital HL & 49 & 49 & 19 & A \\
\hline B6 & $\mathrm{F}$ & Sudden SNHL & 44 & 4 & 20 & A \\
\hline B7 & $\mathrm{F}$ & Meniere' disease & 62 & 10 & 21 & A \\
\hline B8 & $\mathrm{F}$ & COM & 61 & 13 & 13 & B \\
\hline B9 & M & Unknown & 59 & 10 & 12 & A \\
\hline B 10 & $\mathrm{~F}$ & Congenital HL & 59 & 59 & 12 & B \\
\hline B 11 & $\mathrm{~F}$ & COM & 63 & 15 & 12 & B \\
\hline $\mathrm{B} 12$ & $\mathrm{~F}$ & Unknown & 64 & 2 & 12 & B \\
\hline $\mathrm{B} 13$ & $\mathrm{~F}$ & Unknown & 62 & 1 & 12 & B \\
\hline B 14 & $\mathrm{~F}$ & Unknown & 26 & 10 & 12 & B \\
\hline B 15 & M & $\mathrm{COM}$ & 49 & 20 & 10 & B \\
\hline B 16 & $\mathrm{~F}$ & COM & 53 & 40 & 9 & A \\
\hline B 17 & $\mathrm{~F}$ & $\mathrm{COM}$ & 53 & 17 & 10 & B \\
\hline B 18 & $M$ & Congenital HL & 41 & 41 & 5 & A \\
\hline B19 & M & Sudden SNHL & 62 & 1 & 3 & B \\
\hline \multicolumn{7}{|c|}{ CROS HA } \\
\hline $\mathrm{Cl}$ & $\mathrm{F}$ & Sudden SNHL & 44 & 10 & 3 & B \\
\hline $\mathrm{C} 2$ & $\mathrm{~F}$ & COM & 47 & 40 & 3 & B \\
\hline C3 & M & Unknown & 28 & 4 & 3 & $A$ \\
\hline $\mathrm{C} 4$ & $\mathrm{~F}$ & Unknown & 77 & 10 & 3 & B \\
\hline C5 & $\mathrm{F}$ & Unknown & 56 & 10 & 3 & B \\
\hline C6 & $\mathrm{F}$ & COM & 71 & 5 & 3 & B \\
\hline$C 7$ & M & COM & 63 & 50 & 3 & B \\
\hline C8 & M & Unknown & 42 & 2 & 4 & A \\
\hline C9 & $M$ & Unknown & 60 & 2 & 3 & B \\
\hline
\end{tabular}

*all patients divided to group A or group B according to hearing level of better ear (group A is normal hearing in better ear and group B is mild/moderate HL in better ear). BAHA: bone anchored hearing aid, COM: chronic otitis media, HL: Hearing loss, SNHL: sensorineural hearing loss, CROS HA: contralateral routing of signal hearing aid 
일측성 전농의 기준은 순음청력검사상 청력 역치가 $90 \mathrm{~dB}$ 이상이고, 어음분별치가 $20 \%$ 미만으로 하였다. 일측성 전농 환자 28명 중 8명은 반대측 좋은 귀가 정상 청력(순음청력검 사상 청력 역치 $25 \mathrm{~dB}$ 이상, 어음분별치 $80 \%$ 이상)이었고, 나 머지 20명은 경도에서 중등도의 감각신경성 난청(순음청력검 사상 청력 역치 25 50 dB, 어음분별치 75 90\%)이었다. 일측 성 난청의 원인은 만성중이염이 가장 많았고, 원인미상, 돌발성 난청, 선천성 난청, 메니에르병의 순이었다. 또한 좋은 귀의 청 력이 정상인 경우를 그룹 $\mathrm{A}$, 좋은 귀의 청력이 경도에서 중등 도의 난청이 있는 경우를 그룹 B로 분류하였다(Table 1). 본 연 구는 헬싱키 선언을 준수하여 연구가 진행되었다.

\section{청력 재활 수단}

BAHA(Cochlear)는 2009년 1월부터 2012년 4월까지 시술 되었으며, 모든 환자에서 BP100 모델을 사용하였다. BAHA는 무선 $\mathrm{CROS}$ 보청기가 출시되기 전 일측성 전농 환자의 주된 청력 재활 수단으로 사용되었다. CROS 보청기의 경우 Phon-

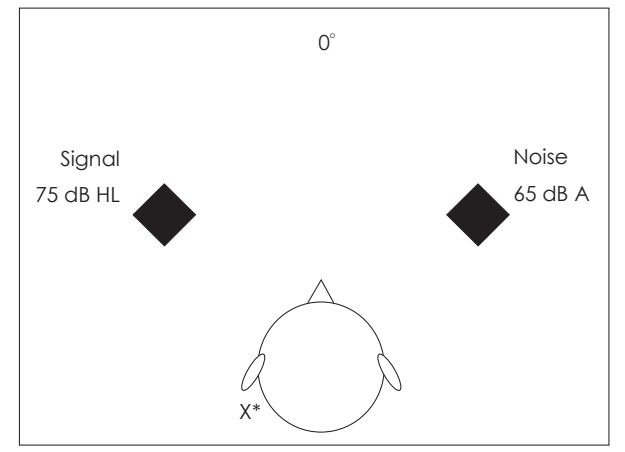

Fig. 1. Speaker configurations for HINT. The subject was seated $1 \mathrm{~m}$ from the speaker arc. * $X$ means deaf ear. HINT: hearing in noise test. ak사의 모델 중 나쁜 귀에는 CROS BTE(Stäfa, Switzerland) 를 사용하였고, 좋은 귀에는 Audéo S SMART III(Stäfa, Switzerland)를 사용하였다.

\section{방 법}

상기 대상 환자의 의무기록을 후향적으로 검토하였으며 순 음청력검사 및 어음청력검사를 시행하였다. 객관적 평가를 위해 보청기 미 착용시(unaided) 헤드폰을 이용하여 청력 역치 및 어음명료도치를 검사하였으며, 음장(sound field) 검사로 $\mathrm{BAHA}$ 및 $\mathrm{CROS}$ 보청기 착용시 청력 역치 및 어음명료도치를 검사하였다. 또한 hearing in noise test(HINT)를 음장 검사 로 시행하였다. HINT는 환자로부터 $1 \mathrm{~m}$ 떨어진 두 개의 스피 커를 이용하여 나쁜 귀 쪽에 $75 \mathrm{~dB} \mathrm{HL}$ 의 신호를 주었고, 좋은 귀 쪽에서 $65 \mathrm{dBA}$ 의 소음을 주었다[signal to noise ratio=10, $10 \mathrm{~dB}(\mathrm{~S} / \mathrm{N})]$ (Fig. 1). HINT 검사시 문장은 한국표준문장표 (Korean Standard-Sentence List for adults, KS-SL-A)를 사용하였으며, 총 40 개의 목표어절 중 환자가 맞게 대답한 어절 개수를 퍼센트로 산출하였다. KS-SL-A는 일상생활의 문장을 사용하여 어음인지도를 검사하도록 CID 일상생활 문 장 검사(Central Institute for the Deaf Every day Sentences Test)의 문장선정기준과 한국어 및 청각학적 특성을 고려하여 제작되었으며, 만 13세 이상을 대상으로 사용할 수 있도록 되 어 있다. ${ }^{4}$

주관적 평가를 위해서는 Bern Benefit in Single-Sided Deafness Questionnaire(BBSS)를 사용하였다. BBSS는 Kompis 등에 의 의해 일측성 전농 환자에게 BAHA가 도움이 되는지 를 알아보기 위해 개발되었다. 총 10 개의 항목으로 구성되어 있으며, 1번 항목부터 9번 항목까지 9가지 상황에서의 만족

Table 2. Bern benefit in single-sided deafness questionnaire

Please rate your perceived benefit from your aid in the following situations by a vertical line.

1. To hold a conversation with one person in a quiet environment. For me, this is:

2. To understand a TV or a radio speaker. For me, this is:

3. To listen to music. For me, this is:

4. To follow a conversation from some distance ( $5 \mathrm{~m} / 15 \mathrm{ft}$ or more). For me, this is:

5. To follow a conversation with background noise. For me, this is:

6. To hold a conversation while driving in a car. For me, this is:

7. To understand speech in a reverberant room, such as a large entrance hall or a church. For me, this is:

8. To participate in a group conversation with 3 or more participants. For me, this is:

9. To localize a sound source, such as a honking car. For me, this is:

10. Over all, for me hearing is:

\begin{tabular}{|c|c|c|c|c|c|c|c|c|c|}
\hline \multicolumn{2}{|c|}{$\begin{array}{l}\text { Much easier } \\
\text { without the aid }\end{array}$} & \multicolumn{3}{|c|}{$\begin{array}{c}\cdots \text { somewhat } \\
\text { easier }\end{array}$} & \multicolumn{2}{|c|}{$\begin{array}{l}\text { Similar with } \\
\text { and without }\end{array}$} & \multicolumn{2}{|c|}{$\begin{array}{c}\text {-.somewhat } \\
\text { easier }\end{array}$} & $\begin{array}{l}\text { Much easier } \\
\text { with the aid }\end{array}$ \\
\hline-5 & -4 & -3 & -2 & -1 & 0 & 1 & 2 & 3 & 4 \\
\hline$L$ & 1 & 1 & 1 & 1 & 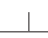 & 1 & 1 & $\perp$ & 1 \\
\hline
\end{tabular}


도와 10 번째 항목의 전반적인 만족도로 구성되며, 각 항목은 -5점부터 5점까지 시각적 아날로그 척도(visual analog scale) 로 조사하도록 구성되어 있다(Table 2). 모든 환자에서 BAHA 나 $\mathrm{CROS}$ 보청기 착용 전에 $\mathrm{BBSS}$ 설문을 시행하였으며, 착용 후에 $\mathrm{BBSS}$ 설문을 다시 시행하여 착용 전, 후의 만족도를 비 교하였다. 하루에 청력 재활 수단을 사용하는 시간(daily device using time)을 조사하고 이것에 영향을 주는 요소(factor)를 알 아보기 위해 사용 시간과 만족도, 사용시간과 좋은 귀의 청력 상태, 사용시간과 원인 질환과의 상관관계를 분석하였다. 또한 BAHA 및 CROS 보청기를 사용하지 않는 환자가 있었다면, 이들에게 사용하지 않는 이유를 조사하였다.

결과 변수에 따라서 SPSS 12.0(SPSS Inc., Chicago, IL, $\mathrm{USA}$ )의 대응표본 $\mathrm{t}$ 검정(paired $\mathrm{t}$ test of difference), 일표본 $\mathrm{t}$ 검정(one-sample t test), 크루스칼-왈리스 검정(Kruskal Wallis test), 상관관계 분석(linear regression)을 사용하였다. 모든 결 과는 mean $\pm \mathrm{SD}$ 로 표현하였으며, $p$-value 0.05 미만인 경우 통계적으로 의미가 있는 것으로 보았다.

\section{결 과}

$\mathrm{BAHA}$ 와 $\mathrm{CROS}$ 두 그룹에서 보청기 착용시 청력 역치가 평

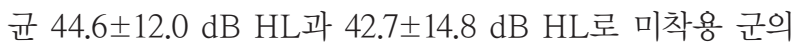
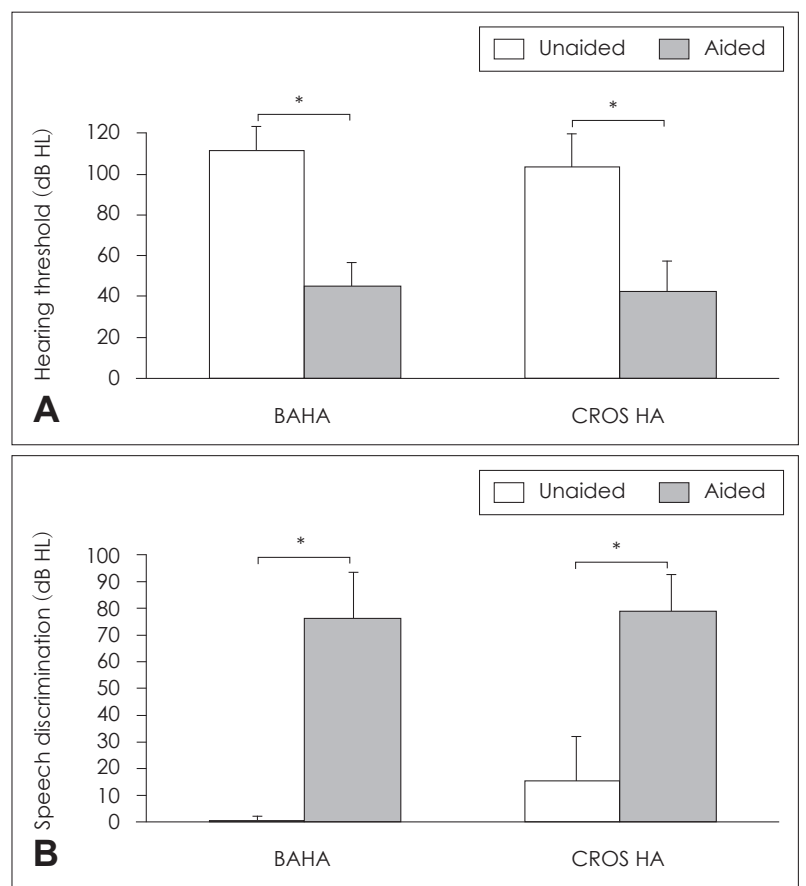

Fig. 2. Unaided and aided pure-tone thresholds (in $d B$ hearing level, $\mathrm{HL}$ ) in BAHA and CROS HA (A). Speech discrimination (in percentage) in BAHA and CROS HA (B)(BAHA $n=19$, CROS HA $n=9$, Paired $t$ test of difference). BAHA: bone anchored hearing aid, CROS HA: contralateral routing of signal hearing aid. ${ }^{*} p<0.05$.
111.3 $\pm 11.9 \mathrm{~dB}$ HL과 $103.3 \pm 16.0 \mathrm{~dB}$ HL에 비해 감소되었고, 어음명료도치 $76.2 \pm 17.2 \%$ 와 $78.6 \pm 13.9 \%$ 로 미착용 군의 0.5 $\pm 1.9 \%$ 와 $15.4 \pm 16.7 \%$ 에 비해 높게 나왔으며, 통계적으로 유 의하였다( $p=0.000)$ (Fig. 2).

$\mathrm{HINT}$ 에서도 BAHA, $\mathrm{CROS}$ 보청기 그룹 모두 보청기 착용 시 $63.0 \pm 28.3 \%, 64.1 \pm 33.3 \%$ 로 미착용시의 $22.1 \pm 25.4 \%, 37.4$ $\pm 26.1 \%$ 에 비해 유의하게 높게 나타났다 $(p<0.0001, p=0.0016)$ (Table 3). BBSS 모든 항목에서 BAHA, CROS 보청기 그룹 모두 청력 재활 수단 착용 후가 착용 전에 비해 모든 항목에서 만족도가 유의하게 높은 것으로 나타났다(BAHA: $p<0.05$, CROS: $p<0.05$ )(Table 4).

하루에 청력 재활 수단을 사용하는 시간은 만족도와 상관 관계가 없었으며(BAHA: $\mathrm{R}^{2}=0.05, p$-value>0.05, CROS: $\mathrm{R}^{2}=0.32, p$-value $>0.05$ )(Fig. 3), 좋은 귀의 청력 역치와도 상 관관계가 없었으며(BAHA: $\mathrm{R}^{2}=0.02, p$-value>0.05, CROS: $\mathrm{R}^{2}=-0.14, p$-value $>0.05$ )(Fig. 4), 청력 소실의 원인 질환과도 상관관계가 없었다 $(p=0.261)$ (Table 5).

총 대상 환자 28명 중 $\mathrm{BAHA}$ 환자 5 명이 하루 중 전혀 착용 을 하지 않는다고 대답을 하였는데, 그 이유는 청력 재활 수 단의 이득(benefit)이 없다는 것 외에 사용시 불편함(inconvenience), 피부 반응(recurrent skin reaction), 피드백 현상(feedback) 발생 등이었다.

요약해 보면 첫째, 일측성 난청 환자에서 BAHA나 CROS

Table 3. Hearing in noise test (BAHA $n=19, \mathrm{CROS} H A n=9$, paired $t$ test of difference)

\begin{tabular}{lccc}
\hline & $\begin{array}{c}\text { Unaided (\%) } \\
\text { mean } \pm \text { SD }\end{array}$ & $\begin{array}{c}\text { Aided (\%) } \\
\text { mean } \pm \text { SD }\end{array}$ & p-value \\
\hline BAHA & $22.1 \pm 25.4$ & $63.0 \pm 28.3$ & $<0.0001$ \\
CROS HA & $37.4 \pm 26.1$ & $64.1 \pm 33.3$ & 0.0016 \\
\hline
\end{tabular}

BAHA: bone anchored hearing aid, CROS HA: contralateral routing of signal hearing aid, SD: standard deviation

Table 4. Bern benefit in single-sided deafness questionnaire (onesample $t$ test)

\begin{tabular}{ccrcr}
\hline Question & $\begin{array}{c}\text { BAHA } \\
\text { mean } \pm \text { SD }\end{array}$ & p-value & $\begin{array}{c}\text { CROS HA } \\
\text { mean } \pm \text { SD }\end{array}$ & p-value \\
\hline 1 & $2.7 \pm 1.6$ & $<0.0001$ & $2.8 \pm 1.4$ & 0.0003 \\
2 & $2.6 \pm 1.8$ & $<0.0001$ & $2.2 \pm 1.1$ & 0.0003 \\
3 & $2.2 \pm 1.6$ & $<0.0001$ & $2.2 \pm 1.1$ & 0.0003 \\
4 & $1.6 \pm 1.6$ & 0.0006 & $1.4 \pm 1.0$ & 0.0027 \\
5 & $1.9 \pm 1.7$ & 0.0002 & $1.4 \pm 1.0$ & 0.0013 \\
6 & $1.7 \pm 1.4$ & $<0.0001$ & $2.8 \pm 1.1$ & $<0.0001$ \\
7 & $1.6 \pm 1.7$ & 0.0016 & $2.8 \pm 0.8$ & $<0.0001$ \\
8 & $2.4 \pm 1.3$ & $<0.0001$ & $2.9 \pm 0.8$ & $<0.0001$ \\
9 & $1.4 \pm 1.3$ & 0.0003 & $2.4 \pm 1.2$ & 0.0003 \\
10 & $2.5 \pm 1.5$ & 0.0003 & $3.1 \pm 1.5$ & 0.0003
\end{tabular}

Each numerals indicate visual analog scale. BAHA: bone anchored hearing aid, CROS HA: contralateral routing of signal hearing aid, SD: standard deviation 


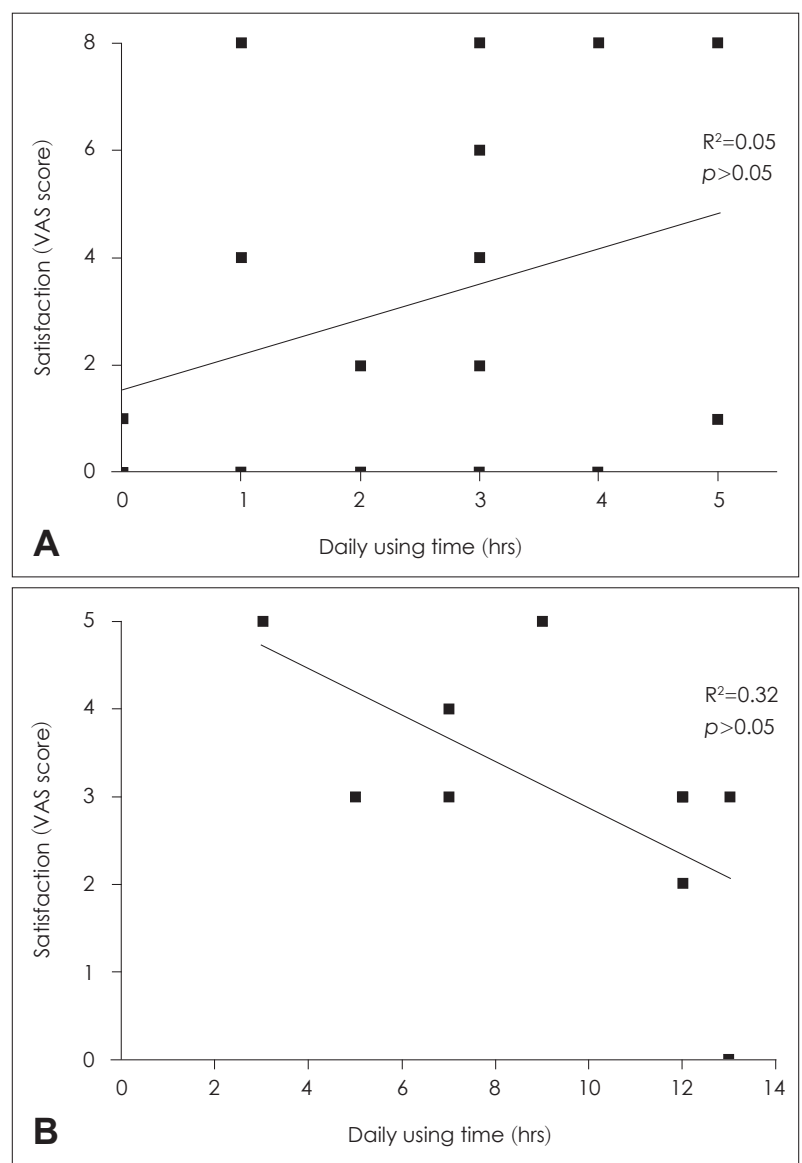

Fig. 3. Correlation between satisfaction and daily using time in BAHA (A), in CROS HA (B) [linear regression, (A): $\mathrm{R}^{2}=0.05, p$-value $>0.05,(B): R^{2}=0.32, p$-value>0.05]. BAHA: bone anchored hearing aid, CROS HA: contralateral routing of signal hearing aid, VAS: visual analog scale.

보청기와 같은 청력 재활 수단은 청각학적인 면에서 기능적 이득이 있다. 하지만, 기능적 이득이 있다고 모든 환자가 해당 청력 재활 수단을 잘 사용하는 것은 아니었으며, 또한 하루 기 기 착용 시간은 만족도, 좋은 귀의 청력 상태, 청력 소실의 원인 과도 특이 상관관계가 없었다.

\section{고 찰}

나쁜 귀 쪽에서 좋은 귀로 소리를 전달시켜 주는 것은 일측 성 전농 환자에서 유용한 청력 재활 방법이며, 대표적인 것이 $\mathrm{BAHA}$ 와 $\mathrm{CROS}$ 보청기다.

본 연구 설계의 특이한 점은 다음과 같다. $\mathrm{BAHA}$ 의 이득을 평가하고자 했던 타 논문들은 BAHA 환자의 HINT 검사시 어음분별력이 $50 \%$ 가 되는 signal to noise ratio(SNR)을 측 정하고 SNR 값이 낮을수록 어음분별력이 높은 것으로 연구 설계를 하였다. ${ }^{6-8)}$ 하지만 본 연구에서는 이와 다르게 SNR 값 을 10 으로 고정하고 이때 어음분별력의 퍼센트를 구하였다. 이

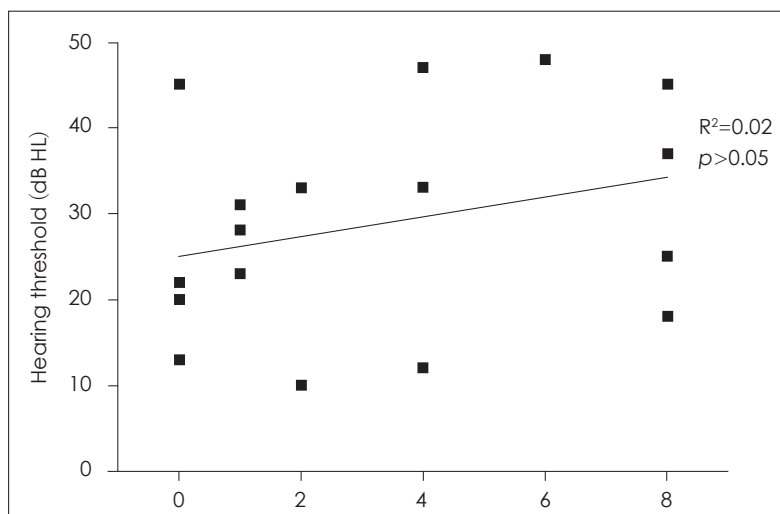

A Daily using time (hrs)

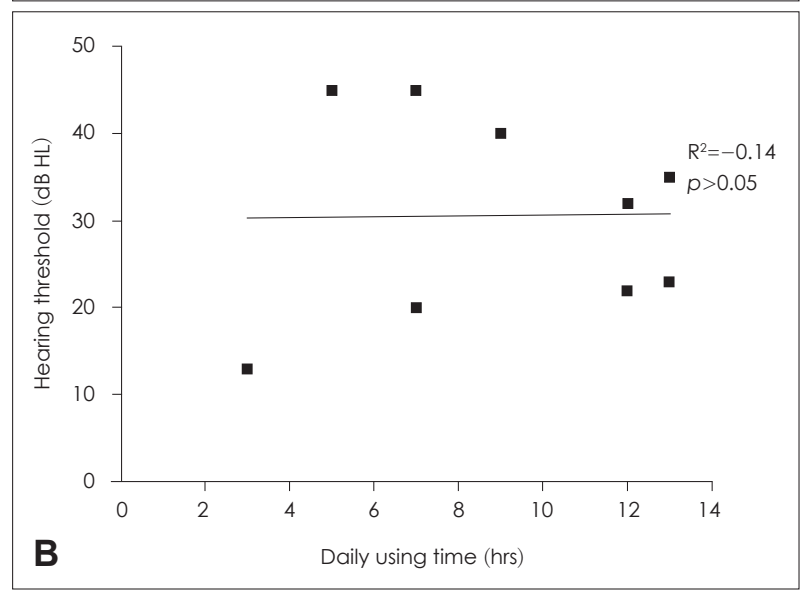

Fig. 4. Correlation between hearing level in better ear and daily use time in BAHA (A), in CROS HA (B)[linear regression, (A): $R^{2}=$ $0.02, p$-value $>0.05,(B): R^{2}=-0.14, p$-value $\left.>0.05\right]$. BAHA: bone anchored hearing aid, CROS HA: contralateral routing of signal hearing aid.

Table 5. Correlation of etiology and daily use time (Kruskal Wallis test)

\begin{tabular}{lc}
\hline & Daily using time (hrs) \\
\hline Chi-square & 5.266 \\
Degree of freedom & 4 \\
p-value & 0.261 \\
\hline
\end{tabular}

것은 환자들이 청력 재활 수단 착용 후 소음환경하에서 향상 된 어음분별력을 쉽게 이해하도록 하기 위한 환자 중심의 설 계(setting)이다. 또한 나쁜 귀에 소음(noise)을 주는 것은 당연 히 나쁜 귀에 소리 신호(signal)를 주는 것보다 어음분별력이 낮게 나올 것이므로 본 연구에서는 이 과정을 생략하였다. 주 관적 평가를 위해 사용된 $\mathrm{BBSS}$ 는 Kompis 등5)이 일측성 난 청 환자에서 $\mathrm{BAHA}$ 를 선택할지 거부할지 의사 결정을 예측할 수 있는 설문으로 의미가 있다고 보고하였고, 현재 일측성 난 청 환자에서 $\mathrm{BAHA}$ 사용 후 주관적 만족도를 확인하는 방법 으로 널리 사용되고 있다.

$\mathrm{BAHA}$ 이식의 가장 흔한 적응증은 만성 이과 질환과 선천 
성 외이도 폐쇄증과 같은 전도성 난청이었으나, 2002년 일측성 난청 환자에 대해서도 Food and Drug Administration 승인 이 되면서 일측성 전농 환자에서 그 적용이 확대되고 있다. BAHA는 난청이 있는 귀 쪽에서 소리를 받아 두개골을 통한 골 전도를 통해 청각 기능이 온전한 반대측 귀로 전달해 주 는 역할을 하게 되며 기본적으로 머리 가림 효과를 최소화 해 준다.9) 무선 CROS 보청기는 기도 전도(air conduction)를 통해 전농 방향에서 들어오는 소리를 마이크가 잡아서 좋은 귀의 원격 계측기 수화기(telemetric receiver) 쪽으로 소리를 전달 해 준다.

과거 일반적 $\mathrm{CROS}$ 보청기는 미용적인 문제로 인한 사회적 낙인, 좋은 귀의 폐쇄 효과(occlusion effect)로 인한 환자 불편 감, 전반적인 불완전한 청력 향상 등의 문제점 등이 있었다. ${ }^{10}$ 하지만 최근 포낙(Phonak, Stäfa, Switzerland)에서 무선 미니 오픈형[wireless mini receiver in the canal(RIC)] 형태가 우리 나라에 들어오면서 수술을 하지 않지 않아도 된다는 점, 비용 이 BAHA에 비해 저렴하다는 점, 스파이스 칩(spice chip)의 개 발로 무선으로도 양 귀의 시간 차이(time difference)를 6 마이 크로 초로 줄여 방향성 구분이 유리한 점, $\mathrm{BiCROS}$ 기능이 있 어 좋은 귀에 경도에서 중등도의 난청이 있는 경우 도움을 받 을 수 있다는 장점이 있다.

본 연구 결과에 따르면, 일측성 난청 환자에서 청력 재활 수 단으로 $\mathrm{BAHA}$ 와 $\mathrm{CROS}$ 보청기 모두 청력 재활 수단을 사용 하지 않았을 때에 비해 청력 역치와 어음분별치가 향상되었 다. 또한 소음환경에서도 BAHA와 $\mathrm{CROS}$ 보청기 사용했을 때 가 사용하지 않았을 때에 비해 HINT 결과 값이 상승하였으 며 주관적인 만족도 조사에서도 두 그룹 모두 만족도가 장치 를 사용하지 않았을 때에 비해서 높았다. 따라서 일측성 전농 환자에서 청력 재활 수단으로서 $\mathrm{BAHA}$ 와 CROS 보청기 모두 객관적, 주관적 측면에서 효과가 있는 것을 알 수 있다.

과거 연구들을 살펴보면 청력 재활 수단에 대한 만족도가 높을수록, $\operatorname{Lin}$ 등은 좋은 귀에 경도 혹은 중등도의 난청이 있을수록, Snik 등1)은 돌발성 난청과 같이 전농 기간(deaf duration)이 짧을수록 청력 재활 수단을 사용하는 시간이 길다 고 주장하였다. 하지만, 본 연구 결과에서 하루에 기기를 착용 하는 시간은 만족도, 좋은 귀의 청력 및 난청의 원인과 특이 상관관계가 없는 것으로 나타났다. 특히 좋은 귀의 청력 정도 와 기기 착용 시간 간에 특이 상관관계가 없다고 나타난 것은 좋은 귀에 경도 혹은 중등도 난청이 있는 경우 청력 재활수 단 사용시 환자의 만족도가 더 높다는 $\operatorname{Lin}$ 등의 의 연구 결과 와는 상반되는 것으로 이것은 추후 더 많은 환자 군에서의 추 가 연구가 필요할 것으로 사료된다.

이와 같이 BAHA와 $\mathrm{CROS}$ 보청기를 사용하는 것이 객관적,
주관적 이득이 있음에도 불구하고 실제로 청력 재활 수단을 사용하지 않는 경우가 있어 환자들이 매일 청력 재활 수단을 사용하는 시간을 조사하였다. 조사 결과 BAHA를 선택한 19 명 중 5명 $(\mathrm{B} 4, \mathrm{~B} 9, \mathrm{~B} 17, \mathrm{~B} 18, \mathrm{~B} 19)$ 이 $\mathrm{BAHA}$ 를 매일 규칙적으 로 사용하지 않았다. 그 이유로는 불편함(B4, B17), 반복적인 염증(B9), 피드백 현상 발생(B18, B19) 등이었다. B17 환자는 직업상 두건을 매일 착용해야 하는데 두건의 아래 면이 $\mathrm{BAHA}$ 와 겹쳐 불편하여 사용하지 않고 있었고, B9 환자는 반복적인 염증으로 2 번 재수술을 시행받았다. 이러한 예들은 청력 재활 수단을 사용하여 이득이 있어도 기기 사용이 불편하거나 염증 이 생기거나 피드백이 발생하면 청력 재활 수단을 사용하지 않는다는 것을 보여준다.

본 연구에서 BAHA 이식 환자 19명 중 2명(B9, B19)은 지 속적으로 접합부(abutment) 위로 피부가 과성장(soft tissue overgrowth)해서 긴 접합부로 교체하였고 이후 불편함이 해소되 었다.

이전 연구에서 Pelosi와 Chandrasekhar ${ }^{12,13)}$ 도 비후성 흥터 (hypertrophic scarring)가 쉽게 생기는 피부를 가진 사람, 두 꺼운 두피를 가진 비만한 남자 환자에서는 $8.5 \mathrm{~mm}$ 접합부를 사용할 것을 권고한바 있다. 따라서 BAHA 이식이 결정된 이 후에도 환자의 여러 가지 상태에 대한 세심한 배려가 필요하다.

B7, B19 환자는 HINT(SNR 10)에서 BAHA 착용시와 미착 용시의 차가 각각 $25.5 \%, 22.5 \%$ 로 평균값 $40.90 \%$ 에 비해 낮 고, 전반적인 만족도(BBSS 10번 항목)도 낮았다. 이것은 두 환 자가 고주파수 난청(high tone loss)으로 저주파수 신호(low tone signal)는 고주파수 소리에 비해 머리 가림 효과의 영향 을 덜 받아 비교적 반대측으로 잘 넘어가기 때문에 좋은 귀로 전달된 저음역 신호와 열세 귀 측에서 증폭된 저주파수 신호 가 혼합되어 소음하 어음 분별력이 저하되어 나타난 결과로 생 각된다. 이전의 Pfiffner 등 ${ }^{14}$ 은 일측성 난청 환자에서 저주파 수 신호를 감쇠시킴으로써 BAHA를 통해 나타나는 소리의 왜곡이 감소될 수 있다고 보고한바 있다. 이는 BAHA를 맞춤 시 일반적인 기도 보청기 맞춤과는 다른 전략 및 청각사의 숙 련도가 요구됨을 보여준다.

본 연구 대상의 $71 \%$ 가 좋은 귀에 경도의 난청을 가지고 있 었기 때문에 좋은 귀의 청력 상태에 따라 연구 대상을 그룹 $\mathrm{A}$ 와 그룹 $\mathrm{B}$ 로 나누어서 두 군의 만족도를 비교해 보았다.

본 연구의 한계점은 $\mathrm{BAHA}$ 군은 2009년부터 모여진 것에 비해, 무선 CROS HA 군은 2012년 4월 국내에서 판매가 시 작되어 $\mathrm{CROS}$ 보청기 환자수가 적다는 것이다. 따라서 크로 스 보청기 환자수가 더 모이면 두 기기에 대한 이득 비교 및 선 택 기준(selection criteria)에 대한 결과가 나올 수 있으리라 기대한다. 방향성(sound localization) 인식과 관련하여 이전 
의 연구들은 BAHA는 방향성을 향상시키지는 못한다고 보 고하였다. ${ }^{8,15,16)}$ 포낙은 이번에 출시된 $\mathrm{CROS}$ 보청기는 양 귀 간의 시간차를 6마이크로 초로 줄여 방향성을 향상시킨다고 주장하고 있으나 이에 대한 타당성 역시 $\mathrm{CROS}$ 보청기 환자수 가 늘어난 이후 연구가 이루어져야겠다.

본 연구 이전에 본원에서는 일측성 난청 환자에게 청력 재활 수단을 정할 때 술 전 BAHA 로드 테스트(BAHA rod test)나 보청기 구매 전 시험 착용으로 이득(functional gain)을 확인 하고 청력 재활 수단을 권하였다. 하지만 본 연구 결과에 따르 면, 청각학적 이득이 있다고 모든 환자가 청력 재활 수단을 잘 사용하는 것은 아니며, 청력 재활 수단 사용 시간은 만족도, 좋 은 귀의 청력 정도, 난청의 원인과도 특이 상관관계가 없을 가 능성이 있다는 것을 염두에 두어야 할 것으로 사료된다.

따라서 재활 수단 결정 전에 기능적 이득만 따질 것이 아니 라, 개인의 직업, 피부 성상 등 개인에 맞춰진 상담(customized counseling) 및 자세한 사전 상담이 필요하겠다.

\section{REFERENCES}

1) Douglas SA, Yeung P, Daudia A, Gatehouse S, O’Donoghue GM. Spatial hearing disability after acoustic neuroma removal. Laryngoscope 2007;117(9):1648-51.

2) Welsh LW, Welsh JJ, Rosen LF, Dragonette JE. Functional impairments due to unilateral deafness. Ann Otol Rhinol Laryngol 2004;113(12): 987-93.

3) Kang SH, Goh EK, Koo JW, Kwon KH, Kwon SH, Kim KR, et al. Otorhinolaryngology Head and Neck Surgery. 2nd ed. Seoul, Korea: Iljogak;2009. p.821-2.

4) Lee JH, Cho SJ, Kim JS, Chang HS, IM DH, Lee KW, et al. Korean Speech Audiometry. 1st ed. Seoul, Korea: Hakjisa;2010. p.2.

5) Kompis M, Pfiffner F, Krebs M, Caversaccio MD. Factors influencing the decision for Baha in unilateral deafness: the Bern benefit in single-sided deafness questionnaire. Adv Otorhinolaryngol 2011;71: 103-11.

6) Lin LM, Bowditch S, Anderson MJ, May B, Cox KM, Niparko JK. Amplification in the rehabilitation of unilateral deafness: speech in noise and directional hearing effects with bone-anchored hearing and contralateral routing of signal amplification. Otol Neurotol 2006; 27(2):172-82.

7) Bronkhorst AW, Plomp R. Binaural speech intelligibility in noise for hearing-impaired listeners. J Acoust Soc Am 1989;86(4):1374-83.

8) Hol MK, Bosman AJ, Snik AF, Mylanus EA, Cremers CW. Boneanchored hearing aids in unilateral inner ear deafness: an evaluation of audiometric and patient outcome measurements. Otol Neurotol 2005;26(5):999-1006.

9) Han KH, Kim H, Jang JH, Yoo JC, Kim YH, Lee JH, et al. Hearing rehabilitation with bone anchored hearing aid: experience in 14 patients. Korean J Otorhinolaryngol-Head Neck Surg 2010;53(12): 755-60.

10) Gelfand SA. Usage of CROS hearing aids by unilaterally deaf patients. Arch Otolaryngol 1979;105(6):328-32.

11) Snik AF, Mylanus EA, Cremers CW. The bone-anchored hearing aid in patients with a unilateral air-bone gap. Otol Neurotol 2002; 23(1):61-6.

12) Pelosi S, Chandrasekhar SS. Soft tissue overgrowth in bone-anchored hearing aid patients: use of $8.5 \mathrm{~mm}$ abutment. J Laryngol Otol 2011; 125(6):576-9.

13) Monksfield P, Ho EC, Reid A, Proops D. Experience with the longer $(8.5 \mathrm{~mm})$ abutment for Bone-Anchored Hearing Aid. Otol Neurotol 2009;30(3):274-6.

14) Pfiffner F, Kompis M, Flynn M, Asnes K, Arnold A, Stieger C. Benefits of low-frequency attenuation of baha ${ }^{\circledR}$ in single-sided sensorineural deafness. Ear Hear 2011;32(1):40-5.

15) Snik AF, Mylanus EA, Proops DW, Wolfaardt JF, Hodgetts WE, Somers T, et al. Consensus statements on the BAHA system: where do we stand at present? Ann Otol Rhinol Laryngol Suppl 2005;195: 2-12.

16) Wazen JJ, Ghossaini SN, Spitzer JB, Kuller M. Localization by unilateral BAHA users. Otolaryngol Head Neck Surg 2005;132(6): 928-32. 